\title{
Linguistic and Philological Variants in the Papyri: A Reconsideration in Light of the Digitization of the Greek Medical Papyri*
}

\author{
Nicola Reggiani
}

It might be not so original to start with the traditional description of a variant as a deviation of a text from its archetype, but here exactly lies the similarity between linguistic and philological variants, on which the following pages will be focused. Both conceal the assumption that we need to emend a text in order to reach a virtual textual exactness with reference to one, single archetype, and in both cases the critical editor will print what he assumes to be the 'correct' form in the text, relegating the deviating 'anomaly' in the apparatus.

While a philological variant is usually defined after a comparison with another version of the same text, papyrus documents in most cases appear to be unique texts. ${ }^{1}$ They are, according to the terminology of textual criticism, 'single witnesses', and their 'variants' and 'errors' are usually intended as related not to an archetypical text, but to a standard reference language: Koine Greek. One of the most striking editorial outcomes of the choice of this 'linguistic archetype' is the somehow fluctuating treatment of word forms that deviates from 'classical' Greek. ${ }^{2}$ As a tacit rule, what is in fact a 'linguistic variant' with respect to classical Greek is assumed to be the 'regular' form, in a more or less conscious consideration of the cultural and linguistic environment of the papyri from Graeco-Roman Egypt. Nevertheless, the situation is not that clear, and sometimes we do find sporadic editorial 'regularizations' that do not relate to outright scribal mistakes, ${ }^{3}$ as traces of

\footnotetext{
* This lecture was first delivered in Trier on June 30, 2016, in the framework of the "Vorträge im Rahmen des Kolloquiums 'Probleme des griechisch-römischen Ägypten'”. My grateful thanks to Fabian Reiter for the kind invitation. An updated Italian version has been presented at the "Greek Medical Papyri" conference. The paper falls into the project "Online Humanities Scholarship: A Digital Medical Library Based on Ancient Texts" (ERC-AdG-2013-DIGMEDTEXT, Grant Agreement No. 339828, Principal Investigator: Prof. Isabella Andorlini), funded by the European Research Council at the University of Parma.

${ }^{1}$ Cf. Youtie, Criticism, 13-15. For the cases of copies and duplicates, see below.

${ }^{2}$ A thorough discussion of this topic can be found in Stolk, Encoding.

${ }^{3}$ The most typical example is constituted by the verbal voices of ginomai, Koine form of classical gignomai (For the loss/assimilation of gamma before $n y$ cf. Mayser, Grammatik I, 164-6 [Ptolemaic age]; Gignac, Grammar I, 176 [Roman age]; in the Byzantine age gamma comes back), which in the
} 
inconsistencies in the architecture of the linguistic standard.

The situation gets more and more blurred as we gradually enter the quicksand of the linguistic variations that affect the language of the papyri. Even when we look at the most frequently attested cases in the Greek documentary papyri, we do find persistent uncertainties. Let us consider, for example, the most widespread case of the well-known iotacism, phonetic exchange between iota and epsilon-iota, which "indicates the identification of the classical Greek /ei/ diphthong with the simple vowel /i/". ${ }^{4}$ Our test-case word will be $\dot{\rho} \mu \eta v \varepsilon i ́ \alpha$, a fascinating term meaning from time to time "translation", "interpretation", "conversion", and occasionally some sort of tax..$^{5}$ Out of the 25 occurrences in which the full spelling can be recognized with certainty, 17 exhibit the 'standard' form ending in $-\varepsilon 1 \alpha$, while 8 feature the iotacized 'variant' $\dot{\varepsilon} \rho \mu \eta v i ́ \alpha$. Among the latter, in 5 cases the editors decided to 'regularize' the form by indicating the 'standard' reading in the apparatus (two cases are weird in that the re-editions of the papyri get rid of the regularization in the apparatus). In three cases the term is printed as it is, without any further critical annotations, in spite of the existence of strict parallels showing the 'regular' spelling.

This had a not insignificant outcome in terms of the texts digitized in the Duke Databank / Papyri.info database, in that the editors' original reading was retained, generating an evident loss of information in the use of the database. I recently experienced the effects of this shortcoming in person: searching for all the occurrences of $\dot{\varepsilon} \rho \eta \eta v \varepsilon i \alpha$, at first I got just a partial result. I have therefore emended the digital texts by adding the 'regularized' reading in the apparatus of the three papyri, but the extent of the problem is clear, and not yet solved - note the treatment of the supplied word in BGU I 326,i,1: all the printed editions present the iotacized variant, yet the database encoded the 'regular' spelling, and my proposal to fix this has been rejected, as an 'archetype' has been preferred to the attested variant.

The following table illustrates the situation:

papyrus editions are never noted as variants but treated as standard: cf. Depauw/Stolk, Variation, 2134. Editorial regularizations seem to occur only when the verb is affected also by iotacism, often in





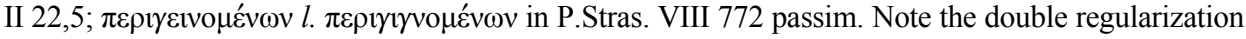

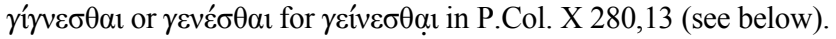

${ }^{4}$ Cf. Gignac, Grammar I, 189; cases: ibid., 189-91. For the Ptolemaic age, with thorough discussion of the phenomenon, cf. Mayser, Grammatik I, 87-94.

${ }^{5}$ Cf. Reggiani, Tradurre. 


\begin{tabular}{|c|c|c|c|c|c|}
\hline Papyrus & Text & Ed.pr. & Following editions & DDB & Notes \\
\hline \multicolumn{6}{|l|}{ REGULARIZED } \\
\hline $\begin{array}{l}\text { P.Kell. I 53,11 } \\
\text { (IV AD) }\end{array}$ &  &  & - & Reg. & - \\
\hline $\begin{array}{l}\text { P.Lund VI } 5 \text { (1),3 } \\
\&(2), 2 \\
(\text { AD } 187 \& 188)\end{array}$ &  & $\begin{array}{l}\dot{\varepsilon} \rho \mu \eta v i ́ \alpha \varsigma, \\
\text { 1. } \dot{\varepsilon} \rho \mu \eta v \varepsilon i ́ \alpha \varsigma\end{array}$ & $\begin{array}{l}\text { SB VI 9355: } \\
\dot{\varepsilon} \rho \mu \eta v i ́ \alpha \varsigma\end{array}$ & Reg. & $\begin{array}{l}\text { SB is a mere re- } \\
\text { print of the ed.pr., } \\
\text { but without appa- } \\
\text { ratus; fortunately, } \\
\text { the DDB follow- } \\
\text { ed the ed.pr:; } \\
\text { Bingen, Review, } \\
153 \text { quotes } \\
\text { straightforwardly } \\
\dot{\varepsilon} \rho \mu \eta v \varepsilon i ́ \alpha \varsigma\end{array}$ \\
\hline $\begin{array}{l}\text { P.Monts.Roca IV } \\
71,3 \text { (AD 141-142) }\end{array}$ & 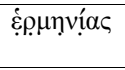 &  & - & Reg. & - \\
\hline $\begin{array}{l}\text { P.Thead. 13,ii,15 } \\
\text { (AD 321) }\end{array}$ & $\dot{\varepsilon} \rho \mu \eta v^{\prime} \alpha$ &  & 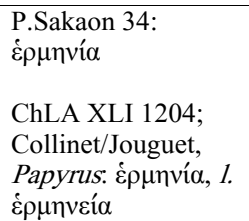 & Reg. & $\begin{array}{l}\text { Fortunately, the } \\
\text { DDB followed } \\
\text { the ed.pr!! }\end{array}$ \\
\hline \multicolumn{6}{|c|}{ NOT REGULARIZED } \\
\hline $\begin{array}{l}\text { BGU I 326,ii, } 15 \\
\text { (AD 194) }\end{array}$ &  & $\dot{\varepsilon} \rho \mu \eta v i ́ \alpha$ & $\begin{array}{l}\text { Chr.M. 316; Sel.Pap. } \\
\text { I 85; FIRA² III 50; } \\
\text { Jur.Pap. 25: } \dot{\varepsilon} \rho \mu \eta v i ́ \alpha\end{array}$ & Emended & $\begin{array}{l}\text { Note at i } 1 \text { the sup- } \\
\text { plement } \dot{\varepsilon} \rho \mu \eta v \varepsilon i] \alpha \\
\text { in DDB (not in the } \\
\text { editions): lectio } \\
\text { facilior! }\end{array}$ \\
\hline $\begin{array}{l}\text { SB X 10288 (2) } \\
\text { [Polotsky, Docu- } \\
\text { ments] } \\
\text { (AD 132) }\end{array}$ &  &  & $\begin{array}{l}\text { Lewis, Documents, } \\
\text { P.Yadin I 27, 15: } \\
\varepsilon \rho \mu \eta{ }^{\prime} \alpha\{\varsigma\}\end{array}$ & Emended & $\begin{array}{l}\text { 'Regular' spelling } \\
\text { in P.Yadin } 11,30 \\
\text { and } 16,33 \& 36 \\
\text { (parallel passages) }\end{array}$ \\
\hline $\begin{array}{l}\text { P.Fay. 23,12 } \\
\text { (AD 131) }\end{array}$ & $\dot{\varepsilon} \rho \mu \eta v i ́ \alpha \varsigma$ & $\dot{\varepsilon} \rho \mu \eta v i ́ \alpha \varsigma$ & - & Emended & $\begin{array}{l}\text { 'Regular' spelling } \\
\text { in P.Oxy. XXVII } \\
2472,3 \text { where the } \\
\text { same official title } \\
\text { occurs }\end{array}$ \\
\hline
\end{tabular}

So far, so good: we have noted how 'irregular' word forms can be irregularly dealt with by modern editors, as well as the not negligible outcomes of such circumstances in terms of digitized texts. Which begs the question: is the choice of a linguistic archetype effective for contexts in which linguistic changes occurred? ${ }^{6}$ More generally speaking, can the choice of a linguistic archetype be

${ }^{6}$ This is the case, for example, with later Egypt, when the use of dative in the Greek language of the papyri experiences a general shift to genitive, on which cf. Stolk, Dative. Thus we can have the case of BGU XIII 2332,20 (AD 375), where vió $\rho \chi \omega+$ genitive ( $\mu$ ov) is regularized in dative ( $\mu \circ$ ) according to the classical use (for more cases of similar variations, see Stolk, Variation, $85 \mathrm{ff}$.), but also the case of SB XVIII 13947,15 (AD 507), where $v \pi \alpha ́ \rho \chi \omega ~+~ d a t i v e ~(\mu o 1)$ is regularized in genitive $(\mu \mathrm{ov})$ as if the latter was then the correct form (cf. Depauw/Stolk, Variation, 213; see also Stolk, Variations, 93). Note that this correction occurs in the Sammelbuch, not in the first edition (Sijpesteijn, Papyri, 138). 
universally effective for a multilingual society? ${ }^{7}$ How much role does the frequency of attestation of a form play? Trevor Evans has recently demonstrated, through examples from the Ptolemaic archive of Zenon, the importance of considering terms of comparison among the papyri themselves in order to conceive a more or less correct idea of linguistic 'standard', or better, in his own words, of "substandard usage in documents of the same place and time":

we should be building our understanding of an emerging standard language in non-literary papyri from this internal evidence much more than from the practices of classical literature, ${ }^{8}$

as he convincingly concludes. Furthermore: how much role do personal consciousness and individual preferences or customary habits play? ${ }^{9}$ In Sir Kenneth Dover's words, "[n]o utterance is such that its author cannot care what it sounds like"; ${ }^{10}$ why shouldn't we care it as well? Should we regularize according to our own linguistic taste, or according to the ancient author's one? Note that the purpose of textual criticism is to establish what an author exactly wrote, and that, by definition, a linguistic variant is any of the different phonetic, morphological, or graphical aspects under which a word can appear in a language, the choice of which can be due to personal reason and preferences, or to archaic, regional, poetic uses.

Let us take into consideration an interesting example of these 'substandards'.



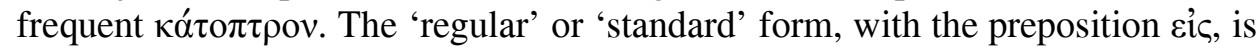
not attested as such in the documentary papyri. It always occurs in linguistic variants that do not correspond, as we might expect, to the iotacised form * attested variant, "̌бo $\pi \tau \rho \circ$, is in fact quite frequently used in literature too, so that it is registered in the main repertories ${ }^{11}$ and is treated as the 'standard' form, without regularizations, in the papyri, where it occurs six times:

\footnotetext{
${ }^{7}$ And for a society at all: but this is another question.

${ }^{8}$ Evans, Standard, 205.

${ }^{9}$ Let us consider what C. C. Edgar called Amyntas' "weakness" for $\dot{\alpha} \varphi \varepsilon ́ \sigma \tau \alpha \lambda \kappa \alpha$ : the preference accorded by one of the main characters of the Zenon archive for the aspirated perfect form of $\dot{\alpha} \pi \circ \sigma \tau \dot{\varepsilon} \lambda \lambda \omega$, instead of the classical $\dot{\alpha} \pi \dot{\varepsilon} \sigma \tau \alpha \lambda \kappa \alpha$ (in the note to P.Cair.Zen. I 59047,1; cf. Evans, Language). This is certainly not a regular form, not even a correct one, but what to think when an author uses with a certain constancy such an irregular form? Shouldn't we assume it as standard (or, according to Evans' terminology, "substandard"), since it was almost systematically (perhaps consciously?) employed by an author? And shouldn't we reverse the situation, positing the classical form as a variant of the idiosyncratic spelling? By the way, the idiosyncratic form is not regularized in P.Cair.Zen. III 59435 + P.Cair.Zen. IV p. 289,3.

${ }^{10}$ Dover, Evolution, 24.

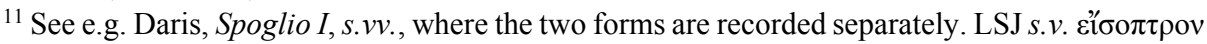


CPR I 21 = SPP XX 31,20: [हैбo $\pi \tau \rho o v]$ [AD 230]

P.Hamb. III 220,7: ๕̌бo $\pi \tau \rho$ ov [AD 223/4]

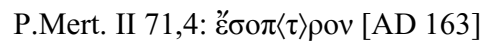

P.Oxy. XXXI 2603,3 ff.: हैбo $\tau \tau \rho o v$ [III-IV AD]

P.Worp 13,ii,28: हैбo $\pi \tau \rho o v$ [III BC]

CPR I 27 = SPP XX 15 = Chr.M. 289,10: हैбo $\pi \tau \rho o v$ [AD 189]

The second attested variant is ö $\sigma 0 \pi \tau \rho o v$. It occurs in the papyri only, and is phonetically explained as a vocalic metathesis of * $*^{\prime} \sigma \pi \tau \rho o v$, being the latter either the

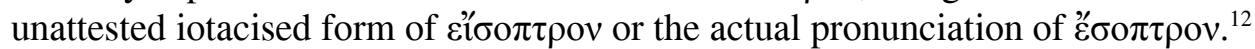
The shift between iota and hypsilon is an unsurprising phenomenon, ${ }^{13}$ and indeed the spelling ö $\sigma i \pi \tau$ pov occurs once (though it would be better to check the reading, since no picture of the papyrus is available online). Another explanation makes it derive directly from हैбo $\pi \tau \rho o v$ through other typical vocalic changes $(/ \mathrm{e} />/ \mathrm{o} /$ and $/ \mathrm{o} />/ \mathrm{u} /),{ }^{14}$ in this case, ö $\sigma i \pi \tau \rho o v$ would be a phonetic variant. Anyway, all the


o’ $\sigma 1 \pi \tau \rho \circ)$ are treated as 'irregular' variants, and regularized sometimes in

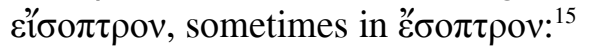

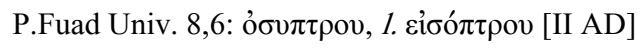



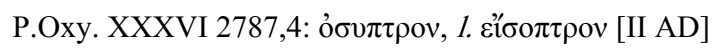

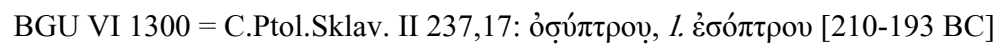

P.Hamb. III 223,11: ỏ $\sigma 0 \pi \tau \rho o v, ~ 1 . ~ \check{\varepsilon} \sigma o \pi \tau \rho o v$ [AD 113]

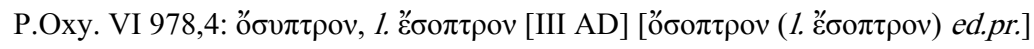

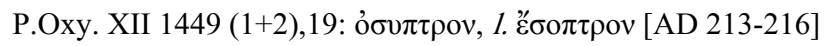

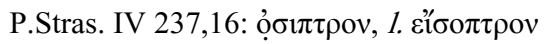

This is apparently weird, in assuming two 'regular' forms for the very same variant. Moreover, it does not take into consideration the possibility. claimed by Isabella Bonati, that őov $\pi \tau \rho o v$ may actually have been a standard (or sub-



${ }^{12}$ Cf. P.Oslo II 46, P.Oxy. XXXVI 2787, C.Ptol.Sklav. II 237, comm. ad locc.

${ }^{13}$ Cf. Mayser, Grammatik I, 151; Gignac, Grammar I, 267-71.

${ }^{14}$ On the whole issue cf. Bonati, Lessico, 246-8, wih further bibliography, and now Bonati/ Reggiani, Mirrors.

${ }^{15}$ See also PGM II 13,752 [AD 346]: the papyrus records the prefix oбvлvpo-, regularized by

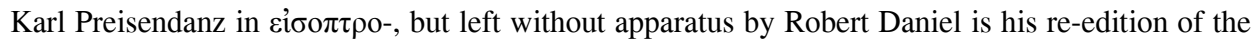
text (Daniel, Papyri, 32-81). 
standard!) form, not only a phonetic variant, being attested as many times as (or even more frequently than) the allegedly standard form हैoo $\tau \tau \rho \circ$, and having produced even a Latin loan word, the osyptrum of ChLA IV 249r,12. The critical uncertainties are of course mirrored by the digital uncertainties: the impression is that the extant syntax to encode linguistic variants - which reflects the current scholarly position - is not really designed to support complex cases or potential substandards, and this turns into simplifications that do not help the research. ${ }^{16}$

When we digitize the text of a papyus, we must take a decision. Digitizing means indeed encoding the text in a machine-readable language that is conventional, logical, precise and standardized. ${ }^{17}$ Any possible uncertainty may result in potential loss of information and therefore in limitations to the enormous potentialities of the database. For example, the current markup tag used to indicate a linguistic variation like the iotacism is called regularization: ${ }^{18}$

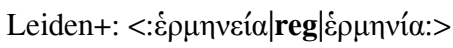

XML (TEI/Epidoc): $<$ choice $><$ reg $>\dot{\varepsilon} \rho \mu \eta v \varepsilon i ́ \alpha</$ reg $><$ orig $>\dot{\varepsilon} \rho \mu \eta v i ́ \alpha</$ orig $></$ choice $>$

HTML: Text: $\dot{\varepsilon} \rho \eta \eta v i ́ \alpha \quad$ App.: l. $\dot{\varepsilon} \rho \mu \eta v \varepsilon i ́ \alpha$

It is evident that behind such a syntax lies the traditional idea that any variant (expressed by the XML tag <orig>, which stands for "original reading") must be brought back to a form that is assumed as regular (the XML tag $<$ reg $>$, i.e. "regularized term"). ${ }^{19}$ This is highly affected by the uncertainty and inconsistency

${ }^{16}$ If I want to collect all the extant attestations of that word in the corpus, I have to know both

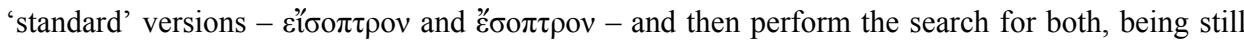
unable to do proximity searches when the word appears in the apparatus. See also the critical observations by Stolk, Encoding, passim.

${ }^{17}$ As is by now known, the encoding language in use is called Leiden+, and is an advanced version of the Leiden editorial conventions for printed editions. Some conventions are the same (e.g. underdots to indicate uncertain letters), some other features are encoded through particular 'tags' (i.e. labels); both can be interpreted by the platform (the Papyrological Editor) and are automatically converted into a standardized markup format called XML and, at the same time, in a human-readable HTML output that looks very close to a traditional print edition (it is important to stress that the XML code contains semantic information which adds meaning to the text, while HTML is purely aimed at displaying the text in a more or less lovely format). Cf. Reggiani, Digital Papyrology I, $234 \mathrm{ff}$.

${ }^{18} \mathrm{Cf}$. <http://www.stoa.org/epidoc/gl/latest/trans-regularization.html > (TEI/EpiDoc); <http://papyri. info/docs/leiden_plus\#orthographic-regularization> (Leiden+). For an historical a critical overview see Stolk, Encoding, $119 \mathrm{ff}$.

${ }^{19}$ Indeed, the syntax to tag the outright scribal mistakes (|corr|) works the very same way. For both, see the thorough discussion by Stolk, Encoding, to which add Reggiani, Digital Papyrology I, 236-7, and Id., Concept, 24-5. It is true that the HTML output display on Papyri.info - where initially the 'regularized' form was shown in the text and the 'original' one in the apparatus, as an earlier Duke Databank legacy - follows now a deeper awareness of scribal phenomenology in displaying the two forms the other way around (as from late 2011, as announced by Sosin, Updates), but the syntax semantics remains the very same. 
in defining a 'standard' form, which is affected - in turn - by discussion about the very nature of linguistic variation: for instance, how should we properly encode



We just considered a couple of cases pertaining to two infrequent words, poorly attested in the corpus. But what about more frequent words? Are such regularizations consistent? First of all, a tool to monitor linguistic variation in the documentary papyri is needed. This tool is now provided by the Trismegistos Database of Text Irregularities, a databank that catalogues all the attested linguistic variants in the papyrus corpus..$^{20}$ It is a first, partial response to an old need, the one already sketched by Paul Maas that " $[t]$ o reach firm ground $[. .$.$] it would be necessary to prepare a$ catalogue of all peculiar errors" ${ }^{21}$ of a textual tradition, and developed from the digital viewpoint by Lorenzo Perilli, who provided some guidelines and desiderata for the construction of a corpus of philological variants to be connected to the TLG database. ${ }^{22}$ The switch from the printed medium, intrinsically limited, to the digital space, which offers potentially endless possibilities of handling the texts, is a momentous occasion for rethinking the concept itself of textual variation (of any kind). On the documentary side, the Sematia platform developed at Helsinki to support the linguistic annotation of the Papyri.info corpus ${ }^{23}$ proceeded along a parallel track in envisaging a "variation" layer (still in progress) that will handle linguistic variants from an innovative viewpoint.

When turning to the literary papyri, and to the technical corpora that are usually addressed as 'paraliterary' or 'subliterary', like medical papyri, philological issues merge with the said linguistic issues, complicating the picture even more. ${ }^{24} \mathrm{~A}$ good example of the situation is P.Aberd. 124 = GMP I 1 (II cent. AD, <http:// litpap.info/dclp/63334>), which preserves, in the first column of the recto, a portion of the Hippocratic treatise De fracturis, paragraph 37 (III 540, 16 L.), on the dislocation of the knee. It is, in its editor's words, a "textually accurate copy of the Hippocratic treatise", which "offers a good Greek text which does not share the banalities of the vulgate tradition". ${ }^{25}$ In this fragment we do find variants

${ }^{20}<$ http://www.trismegistos.org/textirregularities>; cf. Depauw/Stolk, Variation.

${ }^{21}$ Maas, Criticism, 14

${ }^{22}$ Perilli, Filologia, 36-50.

${ }^{23} \mathrm{Cf}$. Vierros/Henriksson, Preprocessing, and Vierros, Annotation; see also below.

${ }^{24}$ The project Digital Corpus of Literary Papyrology (DCLP), held mainly at the Heidelberg Institute of Papyrology, has developed a database similar to the Papyri.info platform but devoted to literary and paraliterary texts on papyrus ( $<\mathrm{http}: / /$ litpap.info $>)$. The endeavour has been as pathbreaking as arduous, since Papyri.info was designed to host documentary texts only and simply did not offer enough tools to treat the special features of literary texts. Many questions are still under discussion, and some pilot projects have contributed with their attempts and suggestions - namely the "Grammatically Annotated Philodemus" \& "Anagnosis" Projects (Würzburg) and the Parma DIGMEDTEXT Project. On the former (and the DCLP in general) see Ast/Essler, Corpus, as well as Reggiani, Digital Papyrology I, 250 ff.; on the latter, see the bibliography in Reggiani, Concept, 8 n. 38 .

${ }^{25}$ Andorlini, De fracturis, 4-5. It is not rarely the case that papyri preserve more genuine text 
already attested in the manuscript tradition: at 11. 4-5 of the papyrus, we read $\tau$ ò $\delta \grave{\varepsilon}$




presence of the second article $\tau$ ov, in accordance with the only testimony of manuscript M (Parisinus 2247), which omits it. ${ }^{26}$ We do find, on the other hand, passages completely divergent from the codices. This is the case with 11. 11-12, where the length of the gap and the shape of the following traces $(\kappa \omega \mid[ \pm 12] \ldots$ ov

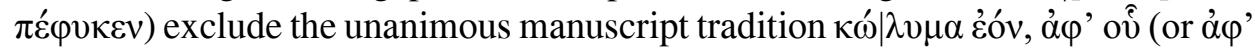



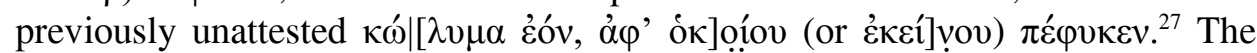
fragmentary state of the papyrus makes things slightly more difficult, but it is clear enough that we are not dealing with the known tradition of the text. A last example is even more interesting, as it merges philological and linguistic issues in one single word: at line 14, where the codices (and the editions) have the 'regular' Ionic form $\pi n \chi \chi \varepsilon \circ \varsigma$, the papyrus shows clearly (as already transcribed by Eric Turner, ed.pr.) $\pi]$ n' $\chi \varepsilon \omega \varsigma$, the Koine form ${ }^{28}$ which is an 'interference' (generating a variation) of a typical form pertaining to the language of the documentary papyri (where, on the contrary, it would be the standard form, as we saw earlier).

How to 'regularize' such occurrences? Is it even possible to speak of 'regularization' at all? In fact, not rarely does linguistic variation, in technical texts especially (but not only!), bear broader cultural significance. ${ }^{29}$ On the phonetic level, 'substandard' forms - equivalents to the abovementioned cases of $\varepsilon \rho \mu \varepsilon v(\varepsilon)$ í $\alpha$ and $\grave{\varepsilon}(1) \sigma o \pi \tau \rho \circ v /$ ó $\sigma 0 \pi \tau \rho \circ v$ - very often betray cultural interferences that deserve more care than distinguishing between 'regular' and 'irregular' forms. Even a 'simple' case such as the fluctuation between $\sigma \mu v \dot{\rho} \rho v \eta$ and $\zeta \mu v ́ \rho v \eta$ "myrrh" can generate hesitations: according to the grammar, $\sigma \mu$ vo $\rho \eta$ should be the 'regular' spelling', while " $\sigma$ is frequently replaced by $\zeta$ before a voiced consonant" ${ }^{30}-$ in the medical papyri indeed, in particular, the term "è scritto quasi regolarmente $\zeta \mu-" .{ }^{31} \mathrm{It}$ is really very difficult to choose a 'regular' form, to which trace a 'variant' spelling back: for example, though Gignac notes that " $\sigma \mu$ - spellings are found especially in Byzantine papyri", ${ }^{32}$ plenty of late antique medical papyri the word is in fact spelled out with

\footnotetext{
versions than the later manuscript tradition: see the observations in Reggiani, Concept, 34 .

${ }^{26}$ Andorlini, De fracturis, 6 and note ad loc.

${ }^{27}$ Andorlini, De fracturis, 5 ("The possibility of a textual variant must be reckoned with") and note ad loc. for detailed discussion.

${ }^{28}$ Andorlini, De fracturis, 6 and note ad loc. with further bibliography on the inconsistency in the Ionic dialect employed by the Hippocratic writers and the papyrus tradition.

${ }^{29}$ Another interesting aspect of these textual fluctuations is that of hypercorrections, which will be dealt with (as regards medical papyri) in Maravela/Reggiani, Scribes.

${ }^{30}$ Gignac, Grammar I, 120 (121-2 on ouv́pvๆ). For the Ptolemaic papyri, see Mayser, Grammatik I, 204.

${ }^{31}$ Andorlini, Ricette, 61 n. 54.

${ }^{32}$ Gignac, Grammar I, 122.
} 
$\zeta \mu-{ }^{33}$ to the extent that it turns into no less than a monogrammatic symbol featuring the character zeta in plain view ( $\&$, in P.Acad. inv. 4,25 [V AD]), ${ }^{34}$ configuring itself as a proper 'substandard' spelling.

There are more complex instances. P.Oslo inv. 1576, a fragment of a catechism dealing with tumour-like diseases, ${ }^{35}$ partly overlaps with the text of P.Oxy. LXXX 5239 (both II-III cent. AD). The scarceness of the surviving portions of text makes it hard to say whether the questionnaire derives from the treatise or they are two different outcomes of a same ascendant. As far as the extant parallel text is

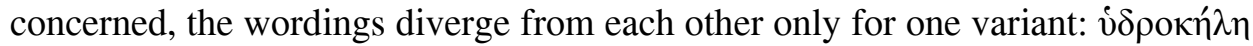


minority variant (LSJ, quoting Poll. IV 203) of the former, used e.g. by Ps.Gal. Def.med. $424=$ XIX 447,12-13 K., but it is in fact attested three times among the medical writers. ${ }^{36}$ Are we facing a trivialization in the Oslo papyrus, or a simple phonetic variant in the Oxyrhynchus papyrus, or just two different traditions bearing the same degree of 'correctness', attesting to a fluid notion of technical language? Moreover, in the following line of the Oslo papyrus (not paralleled by

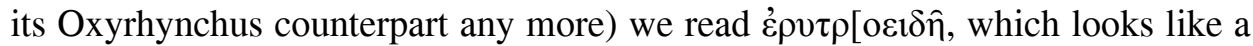
phonetic variant of $\dot{\varepsilon} \lambda v \tau \rho o \varepsilon ı \delta$ ' "lid-like", "cover-like", attribute of one of the membranes enveloping the scrotum. Rho for lambda is indeed a very frequent phonetic exchange in the language of the Greek papyri, ${ }^{37}$ but the same variation is to be found among the manuscripts preserving Ps.Galen's Introductio seu Medicus, containing a descriptive passage (XIV 719,5-10 K.) of the same anatomical part, ${ }^{38}$ making it quite hard to establish degrees of 'regularity' in the spelling employed. ${ }^{39}$

On the morpho-syntactic level, we witness phenomena that go far beyond case variation as thoroughly examined by Joanne Stolk. ${ }^{40}$ In medical prescriptions and

\footnotetext{
${ }^{33}$ See P.Michael. 36 (Byz. age); GMP I 14 = P.Sijp. 6 (IV/V AD); GMP II 8 (V AD); SB XXVIII 17138-17139 (V); MPER n.s. XIII 8 (second half V AD); SB XIV 11964 (V/VI AD); P.Cair.Masp. II 67141 (VI AD?).

${ }^{34}$ On this monogram cf. the observations by Fournet, Papyrus, 319-20. The papyrus is republished in Fournet, Bibliothèque, 185-7.

${ }^{35}$ Maravela/Leith, Catechism. The papyrus will be republished in the forthcoming P.Oslo IV. I am most grateful to Anastasia Maravela for sharing her drafts of the new edition and for discussing with me some textual and linguistic details.

${ }^{36}$ Orib. Syn.Eust. III 28,6 and 9= CMG VI 3, p. 75,15-16 and 21 Raeder; Steph. In Hipp. Progn.



${ }^{37}$ Cf. Gignac, Grammar I, 105.

${ }^{38}$ The previous editors corrected it in $\dot{\rho} \rho \theta \theta \rho o \varepsilon 1 \delta o v ̂ \varsigma$, but the newest Belles Lettres edition (Petit,

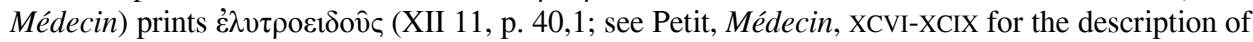
the manuscript tradition). Quite interestingly, the author of the treatise came possibly from Egypt (cf. Petit, Médecin, L-LI), which suggests that the phonetic variation could have worked both ways. I discuss this and the preceding case also in Reggiani, Concept, 28, and Id., Literacies.

${ }^{39}$ For other similar cases cf. Reggiani, Concept, 26-7.

${ }^{40}$ Stolk, Variations; Dative; Encoding. See the case of $v \pi \alpha ́ \rho \chi \omega$ mentioned above.
} 
recipe-like texts, it is remarkably frequent the use of the verb $\chi \rho \alpha$ ó $\mu \alpha$ in the imperative form $\chi \rho \hat{\varphi}$ "use" to introduce specific instructions about the composition of medicaments (typically, "the final formula of a recipe which suggests how an ointment should be mixed and applied"). ${ }^{41}$ This is typically accompanied by the indication of the substance to which the previous compound


II $273=$ GMP II 5,ii,13: $\mu \varepsilon] \tau$ ' ộvov $\chi \rho \hat{\omega} \mathrm{t}$ "use with wine") or of the ingredient to

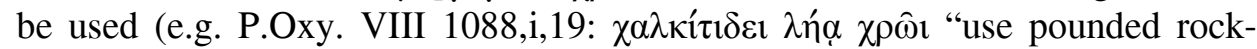
alum"; P.Oxy. LXXIV 4975 (1),4: $\tau \hat{n} \sigma \pi \mathrm{\sigma} \delta \hat{\omega}$ $\chi \rho \hat{\omega}$ "use the powder"). Nevertheless, it is not rarely the case that the syntagm "use with water" appears under the a-syntactic aspect v $\delta \omega \rho \chi \rho \hat{~(e . g . ~ P . T e b t . ~ I I ~} 273=$ GMP II 5,iv,5, vii, 17, viii,5, 22; P.Princ. III 155v,9), ${ }^{42}$ which goes far beyond the apparent 'incorrect' anacoluthon, becoming a distinctive mark of medical recipes. ${ }^{43}$ It would be rather senseless to 'regularize' such peculiar circumstances, for which we may well speak of 'formulaic substandards', which increasingly tend to detach from the syntactic architecture of the discourse and to constitute textual and graphical units, completely released from the context. ${ }^{44}$ An interesting case - not as wellestablished as ' $\forall \delta \omega \rho \chi \rho \hat{\varphi}$ ' and therefore perhaps even more significant - is also given by P.Princ. III 155r,7, where the common instruction "use with wine" is written as otvov $\chi \rho(\hat{\omega})$, in which the genitive is interpreted by Isabella Andorlini as influenced by the genitive endings of all the ingredients listed above (11. 2-6). ${ }^{45}$ Another possibility is that the syntactic flaw is a formulaic derivation of the 'regular' $\mu \varepsilon \tau$ ' o'vov. The absence of parallels prevents us from speaking of 'formualic substandard', but the overall cultural context encourages us to be particularly cautious when dealing with otherwise apparent 'irregularities'.

From the digital viewpoint, the embarrassment in handling such linguistic fluctuations, in which it is not actually possible to identify a 'correct' or even a 'standard' form as opposed to a 'deviant' hypostasis, adds to the difficulties raised by the treatment of philological cases. In the Aberdeen example presented above, a first

\footnotetext{
${ }^{41}$ Andorlini, Prescription, 12. Cf. Gazza, Prescrizioni II, 110-11.

42 The Princeton papyrus is republished by Andorlini, Prescription, 6-11 in this volume.

${ }^{43}$ Cf. Andorlini, Gergo, 163: "I due vocaboli [...] non mantengono alcun legame sintattico con quel che precede, né tra di loro"; also Andorlini, Prescription.

${ }^{44}$ Cf. Andorlini, Gergo, 160-1 n. 39, apropos of PSI XXI Congr. 3: “[n]ella formula [...] l'imperativo pres. di 2 a persona del verbo $\chi \rho \alpha ́$ ó $\mu \alpha 1$ ( $\chi \rho \hat{\omega} 1)$, scritto per esteso e con iota ascritto, e non abbreviato nel consueto monogramma dei testi di età romana $(\mathbb{*})[\ldots]$, è avvertito ormai come asintattico, e si avvia ad assumere la funzione di sigla di chiusura, svincolata dal contesto"; cf. ibid., 163. On the monogram cf. Gazza, Prescrizioni II, 111. On the reduction of the entire formulaic syntagm to a couple of symbols - which stresses its autonomy from the context - cf. Andorlini, Gergo, 163. Sometimes, it is the only word v $\delta \omega \rho$ on its own that is used as a formulaic marker at the end of the prescription (see e.g. SB XXVIII 17139,27).

${ }^{45}$ Andorlini, Prescription, 8.
} 
attempt to cope with the latter has been to use the syntax for the editorial correction (tag |ed|), which is intended to encode the modern interventions on previous editions; the result was nice from the viewpoint of the display, but the semantics were completely incorrect. Another way in which we could encode variants is the syntax for the editorial alternative readings (tag $\mid$ alt $\mid)$, designed to indicate two or more possible readings for the same text. ${ }^{46}$ This might be semantically closer to our intention, but the search functions would be limited $;{ }^{47}$ moreover, if I wanted to add information on the author of an alternative reading, I cannot use this tag, because this function is not supported (as it is, conversely, by the led| tag). Currently, no tool is available to deal with such cases in a proper way. ${ }^{48}$ The possibility of adding a lineby-line commentary can be exploited for this purpose (as we did), but then the information will be searchable with many limitations.

Let us move to an even more puzzling problem. P.Tebt. II 272, verso (late II cent. AD, <http://litpap.info/dclp/60048>), is a fragment of Herodotus Medicus' De remediis, describing the symptomatology of thirst and its treatment; the text corresponds in part to an excerpt of Herodotus Medicus preserved with Oribasius' treatment of thirst in case of fever (Coll.med. V 30,6-7 Raeder = CMG VI 1,1). At

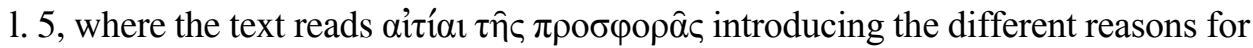
giving the sick something to drink, the scribe adds two groups of three letters between dots above the line: ${ }^{49} * \tau \hat{\omega} v^{*}$ above $\tau \hat{\eta} \varsigma$, and * $\rho \hat{\omega} v^{*}$ above $\rho \hat{\alpha} \varsigma$.

\footnotetext{
${ }^{46}$ For both editorial tags cf. Reggiani, Concept, 43-4.

${ }^{47}$ For example, let us consider a case of iotacism that conceals a double alternative reading: in P.Col.

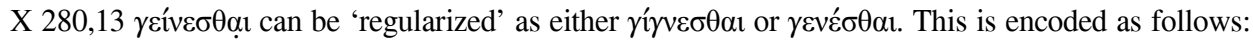

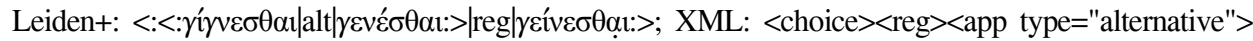
$<$ lem $>$ ý́ $\gamma \varepsilon \varepsilon \sigma \theta \alpha 1</$ lem $><$ rdg $>\gamma \varepsilon v \varepsilon ́ \sigma \theta \alpha</$ rdg $></$ app $></$ reg $><$ orig $>\gamma \varepsilon i ́ v \varepsilon \sigma \theta<$ unclear $>\alpha</$ unclear $>1<1$

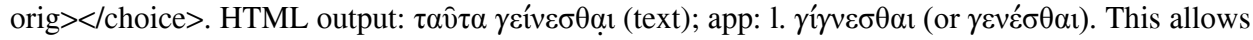
one to perform a proximity search only for the word printed in the text, i.e. the 'irregular' one, so that if I search for passages in which $\tau \alpha \tilde{v} \tau \alpha$ is followed by a word containing $\gamma \varepsilon(\nu$ - within 3 characters of distance, I will find our papyrus (along with another one). Instead, if I search for $\tau \alpha \tilde{v} \tau \alpha$ followed by either $\gamma \iota \gamma \nu$ - or $\gamma \varepsilon v-$, I will not find our papyrus any more.

${ }^{48}$ Documentary papyrologists seem to have some kind of allergy to philological issues. When we have to do with duplicate documents - which would allow them to experience the thrill of a textual collation, and therefore to develop strategies to cope with textual variants - it is usually published one copy (best if the better preserved one), stated that another copy of the same text does exist, and that is about it. Consequently, no tool has been developed to treat digitally such circumstance: an earlier tag, introduced in the Duke Databank of Documentary Papyri to indicate an alternative reading from a duplicate of the same text (cf. Willis, Data Bank, 169-70), has been completely abandoned. On copies and duplicates, which fall into the framework of genetic criticism, see Cribiore, Criticism (in this volume); Jördens, Entwurf; Mirizio, Antigrapha; Ead., Archetypes; Nielsen, Catalog; Stoop, Copies, 185; Yuen-Collingridge/Choat, Copyist; for their digital treatment, cf. Reggiani, Digital Papyrology I, 268 n. 57, and Id., Concept, 35 n. 144. On the philological side, the proposal to use a tag |var| raised some practical and theoretical issues, on which cf. Reggiani, Concept, 35 n. 145.

${ }^{49}$ I thank very much Todd M. Hickey and Derin McLeod for the help in getting a high-resolution picture of the fragment.
} 
When digitizing that, we must find a way to state that:

(1) the scribe juxtaposed some text above the line, but not in the form of an addition supra lineam or infra lineam, since it is clearly a variant of the syntagm below (plural instead of singular). We cannot therefore use the standard way to tag supralinear or interlinear insertions, since it would not make sense.

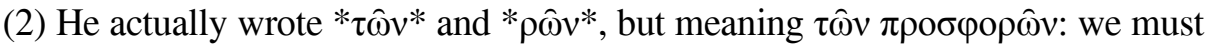
report both readings, since we have to represent what exists on the papyrus but also to be able to search for the full combination of words, and hopefully to find it. For both of these reasons, therefore, we cannot just encode $\tau \hat{\omega} v$ and $\rho \hat{\omega} v$ by themselves.

(3) Since nothing appears deleted, it is not clear if the scribe wanted to correct the text or just juxtapose two different versions of the same passage. In fact there are examples of philological corrections added supra lineam without deletion marks, as well as of deletions indicated by means of overdots (both features are attested in P.Oxy. XXIV 2404, ii 6)..$^{50}$ Otherwise, writing a word between dots can be a way to highlight a correction added later on (see e.g. the koppa in P.Eirene III 25,3, with comm. ad loc.). ${ }^{51}$ We cannot be sure of what is going on here because this variant is unattested in the manuscript tradition, i.e. in Oribasius' passages quoting Herodotus Medicus, which all have the singular form. We would have a scribe correcting the form unanimously preserved by the manuscript tradition and replacing it with an unattested variant. The P.Tebt. editors speak of "correction or alternative reading," Marie-Hélène Marganne of "hésitation." ${ }^{52}$ If we should define it, we ought to call it a 'scribal variant'. And once we define it like that, one main question arises: which is the 'archetype', and which the 'variant'? Once more, we may describe the situation in the line-by-line commentary, but the text itself will lose useful information. The current Papyrological Editor is clearly not trained to treat such cases in a clear and effective way.

The solution I proposed is no more than a trick that exploits the tags intended for editorial corrections and regularizations, with some descriptive comment added:

\section{LEIDEN+}



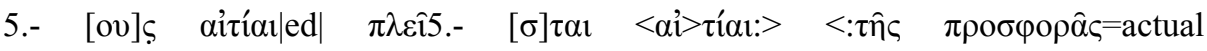
text|ed|*dot* $\tau \hat{\omega} v^{*} \operatorname{dot}^{*}<: \pi \rho о \sigma \varphi \rho \rho \hat{\omega} v|\operatorname{reg}|{ }^{*} \operatorname{dot}^{*} \rho \hat{\omega} v^{*} \operatorname{dot}^{*}:>=$ scribal original insertion above line:> Eiøıv.

\footnotetext{
${ }^{50} \mathrm{Cf}$. Colomo, Osservazioni, 24.

${ }^{51}$ On dots as lectional sigla cf. McNamee, Sigla, 23 (not relevant to us).

${ }^{52}$ Marganne, Fragment, 76.
} 
XML

$<$ milestone rend="paragraphos" unit="undefined"/>


type="editorial" $><$ lem $>\pi \lambda \varepsilon i ́$

$<$ lb n="5" break="no"/><supplied reason="lost">ov</supplied $><$ unclear $>c</$ unclear $>$

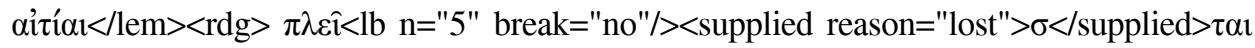

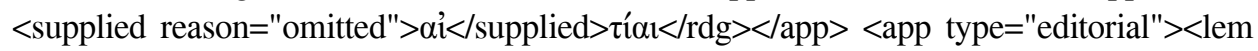
resp="actual text" $>\tau \hat{n} \varsigma \pi \rho о \sigma \varphi о \rho \hat{\alpha} \varsigma</ l e m><\operatorname{rdg}$ resp="scribal original insertion above line" $><$ g type $=$ "dot" $/>\tau \hat{\omega} v<$ g type $=" \operatorname{dot}^{\prime \prime} /><$ choice $><$ reg $>\pi \rho \circ \sigma \varphi \rho \rho \hat{\omega} v</$ reg $><$ orig $><$ g

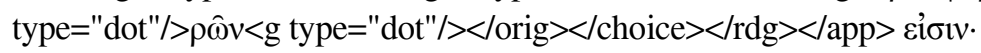

HTML



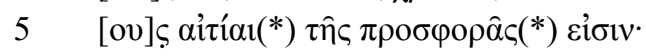

App.:

4-5. $\pi \lambda \varepsilon \hat{\imath} \mid[\sigma] \tau \alpha \imath<\alpha i>\tau i ́ \alpha$ prev. ed.

5. actual text : ((dot)) $\tau \hat{\omega} v((\operatorname{dot}))((\operatorname{dot})) \rho \hat{\omega} v((\operatorname{dot}))(1 . \pi \rho \circ \sigma \varphi \circ \rho \hat{\omega} v)$ scribal original insertion above line $\mathrm{e}^{53}$

It is clealy a tightrope walking, semantically inconsistent, but Leiden+ and TEI/Epidoc XML do not offer anything better for the moment.

Some test cases provided by Federico Boschetti ${ }^{54}$ in the attempt to provide the literary databases such as the TLG with the due critical apparatuses, might direct our steps towards the enhancement of the Leiden+ syntax with tags specifically oriented to treat textual fluctuations, either philological or linguistic. Basically, this would mean to connect more information to the text encoded in the database. What follows is a simple specimen from Boschetti's test case:

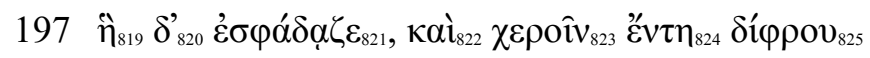

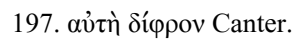

$<\mathrm{itm}>$

$<$ vrs $>197 .</$ vrs $>$

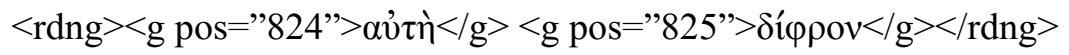

$<$ resp $>$ Canter $</$ resp $>$.

$</$ itm $>$

\footnotetext{
${ }^{53}$ The text has been digitized by student Clara Quartarone during a workshop at the University of Parma.

${ }^{54}$ Boschetti, Methods, 4 ff.
} 
Each word is identified by a unique number; the variants are aligned (i.e. linked) word by word; further information such as the origin of the alternative reading is provided within its own tag (this is not without issues, such as the problem of how to tag broken words).

A significant improvement in the addition of meaningful information comes indeed from linguistic annotation, a powerful methodology developed by corpus linguistics, the branch of linguistic studies that deals with corpora of texts as representative samples of an entire language. Annotating a corpus means to tag textual elements in a systematic way, adding some kind of linguistic information. ${ }^{55}$ It allows to describe, record, interpret and analyse linguistic information at several levels, in which each layer corresponds to a particular category of relevant information that is made available for quantitative analyses and deep search options by means of regular expressions (i.e. combinations of search parameters) and/or XML query strategies. For example, a part-of-speech annotation layer (the one usually known as treebank) connects each token (basic unit of the linguistic corpus) with information about its morpho-syntactic aspect, allowing investigations on the lexical, phraseological, syntactic pattern of the reference language. ${ }^{56}$ Among the others, an annotation layer devoted to variant tagging would significantly improve our textual database..$^{57}$

An annotation layer devoted to textual fluctuations may find a broader application within the concept of transtextuality, as it has been recently analysed by Monica Berti with reference to historiographical fragments. ${ }^{58}$ Transtextuality defines the various possible relations among texts, ${ }^{59}$ and we may refer it not only to a network of quotations and parallel passages ("intertextuality"), ${ }^{60}$ but also to the aspect of fragment which very often the papyrus, be it literary or documentary, shows.$^{61}$ Indeed, we can define the fragmentary character of the papyrus as a sort of 'non-voluntary quotation', selected by the chance and by the material circumstances rather than by an author's will. The transtextual link will work, in this case -

\footnotetext{
${ }^{55}$ To some extent, the Leiden+/XML markup is a kind of non-linguistic, rather semantic annotation.

${ }^{56}$ For an overview of linguistic annotation applied to papyrus texts see Reggiani, Digital Papyrology I, 178-85. For specific projects see Riaño Rufilanchas, Philodemus, and Essler/Riaño Rufilanchas, AristachusX (Herculaneum papyri); Vierros/Henriksson, Preprocessing, and Vierros, Annotation (documentary papyri); Porter/O'Donnell, Phenomena (papyrus letters). I dealt with the topic of linguistic annotation applied to the corpus of the Greek medical papyri in Reggiani, Project (pp. 344 and 347 on variant/error tagging), Perspectives, 2-3, and eventually Concept, 18-27.

${ }^{57}$ Stolk, Encoding, 133-6, persuasively suggests that annotation of linguistic variations should pass through lemmatization of the terms involved.

${ }^{58}$ Cf. Berti/Romanello/Babeu/Crane, Collecting; Berti, Citazioni, 442-7; Ead., Texts; Ead., Representing.

${ }^{59}$ Cf. Reggiani, Concept, 28, with bibliography (namely, with reference to Gérard Genette's textual theory).

${ }^{60} \mathrm{Cf}$. Reggiani, Concept, 33 ff., with bibliography.

${ }^{61}$ Cf. Reggiani, Concept, 16-17.
} 
following the specific terminology -, as a relationship of 'hypertextuality', which describes the derivative connection of a 'hypertext' (in our case, the original document, lost, more or less recoverable in a philological way) with a 'hypotext' (our fragment), showing various degrees of interference: physical and mechanical ones, but also scribal mistakes, linguistic fluctuations, and philological variants. ${ }^{62}$

As with the digital encoding of fragmentary quotations,

hypertextual models allow to rethink the fundamental question of the relation between the fragment and its context, representing and expressing every element of print conventions in a more dynamic and interconnected way. ${ }^{63}$

This perspective would bring innovative solutions to the current question of how to manage the annotation of variants in the papyri. If we cease to consider a variant as a 'deviant version' to be 'corrected' and 'regularized', we can overcome the deadlock by looking at the full set of variants as a network or a system, and by thinking the digital edition as a multitext, a place for a dynamic collation of several editions (or, in our case, versions), stratified in the time (or even at the same time level). As Monica Berti puts it,

collecting multiple critical editions of the same text means building a 'multitext', which is a 'network of versions with a single, reconstructed root', so that scholars can compare different textual choices and conjectures produced by philologists. This process involves a new way of conceiving literary criticism because it produces a representation and visualization of textual transmission completely different from print conventions, where the text that is reconstructed by the editor is separated from the critical apparatus that is printed at the bottom of the page. In addition, the inclusion of images of manuscripts, papyri, and other source materials allows the reader to have a dynamic visualization of the textual tradition and to perceive the different channels of both the transmission and philological production of the text that is usually hidden in the static, concise, and necessarily selective critical apparatuses of standard printed editions. Producing a multitext, therefore, means producing multiple versions of the same text, which are the representation of the different steps of its transmission and reconstruction, from manuscript variants to philological conjectures. This process has fundamental consequences for the study of ancient sources in general and for fragmentary ones in particular, given that, while studying fragments and evaluating their distance from the original version, it is imperative to examine the manuscript variants of the source text,

${ }^{62}$ Cf. Reggiani, Concept, 33 ff. (hypotextuality) and p. 45 n. 187 (fragments as 'virtual' hypotexts).

${ }^{63}$ Berti, Texts, 1. 
in order to see what can be attributed to the witness or to the transmission of the text across centuries. ${ }^{64}$

It is, as has been already pointed out elsewhere, ${ }^{65}$ a completely new and different way of considering critical editions of ancient texts. The texts - in our case, the papyri - becomes meta-texts (meta-papyri) and the critical apparatus dissolves in a network of references, connections, and versions. ${ }^{66}$ This is extremely valuable under the philological circumstances of uneasy textual relations (the 'living' medical texts are a perfect example of this $)^{67}$ as well as in the linguistic cases of fluctuations that cannot actually be handled in terms of plain 'regularizations'. This kind of textual network has also much to do with the ancient philological care as testified by numerous instances (P.Tebt. II 272 verso, decribed above, is just one example): as I contended elsewhere, ancient 'philology' - at least in technical fields such as medicine - was much more interested in a fluid textual transmission (the "accretive model of composition" 68 claimed by Ann Hanson to define the writing history of certain medical texts) rather than in the fixation of a stable (and static), canonical (and constrained), 'correct' version of the texts. ${ }^{69}$

The pathway is still long and perilous, but the first moves have been made: I noticed with pleasure several papers dealing with the treatment of linguistic variants, or related topics, delivered at the latest International Congress of Papyrology at Barcelona (August 2016). I think that from whichever viewpoint one affords the question, the following statement by Greg Crane must unavoidably be kept in mind:

[i]n a digital age, philologists need to treat our editions as components of larger, well-defined corpora rather than as the raw material for printed page layouts. ${ }^{70}$

\section{Bibliography}

Andorlini, Gergo = Isabella Andorlini, Il 'gergo' grafico ed espressivo della ricettazione medica antica, in: A. Marcone (ed.), Medicina e società nel mondo antico (Udine 2005), Firenze 2006, pp. 142-167 [repr. in Ead., Scritti, 15-36].

\footnotetext{
${ }^{64}$ Berti, Texts, 4-5.

${ }^{65}$ Reggiani, Digital Papyrology I, 259 ff.; Id., Concept, passim.

${ }^{66}$ The best way of depicting this framework is the ontology model: cf. Reggiani, Concept, 1-4 and 45-52.

${ }^{67}$ Cf. Reggiani, Concept, esp. 33-43; also Id., Literacies.

${ }^{68}$ Cf. Hanson, Fragmentation, e.g. 305.

${ }^{69}$ Reggiani Transmission.

${ }^{70}$ Crane, Editors.
} 
Andorlini, Prescription = Isabella Andorlini, From Prescription to Practice: The Evidence of Two Medical Papyri from Roman Egypt", in: N. Reggiani (ed.), Greek Medical Papyri: Text, Context, Hypertext. Proceedings of the DIGMEDTEXT International Conference (Parma 2016), Berlin/Boston 2019, 3-17.

Andorlini, Ricette = Isabella Andorlini, Ricette mediche nei papiri: note d'interpretazione e analisi di

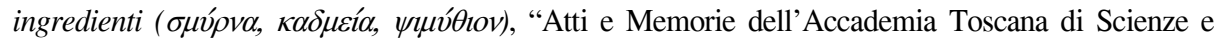
Lettere 'La Colombaria”, 46, n.s. 32 (1981), 33-81 [repr. in Ead., Scritti, 37-48, and Ead., $\pi 0 \lambda \lambda \dot{\alpha}$

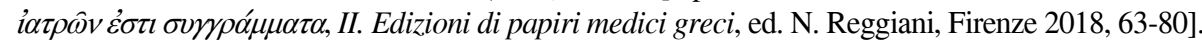

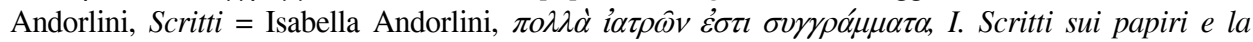
medicina antica, ed. N. Reggiani, Firenze 2017.

Ast/Essler, Corpus = Rodney Ast / Holger Essler, Anagnosis, Herculaneum, and the Digital Corpus of Literary Papyri, in: N. Reggiani (ed.), Digital Papyrology II: New Methods for the Digital Edition of Ancient Greek Papyri, Berlin/Boston 2018, 63-74.

Berti, Citazioni = Monica Berti, Citazioni e dinamiche testuali. L'intertestualità e la storiografia greca frammentaria, in: V. Costa (ed.), Tradizione e trasmissione degli storici greci frammentari, II. Atti del Terzo Workshop Internazionale (Roma 2011), Tivoli 2012, 439-58.

Berti, Representing = Monica Berti, Representing Fragmentary Texts. Some Examples, in: N. Filatkina / C. Moulin / M.-S. Ortola (eds.), Exploring Formulaic Knowledge through Languages, Cultures, and Time, Nancy, forthcoming.

Berti, Texts = Monica Berti, Fragmentary Texts and Digital Libraries, in: G. Crane / A. Lüdeling / M. Berti (eds.), Philology in the Age of Corpus and Computational Linguistics, Washington (DC), forthcoming.

Berti/Romanello/Babeu/Crane, Collecting = Monica Berti / Matteo Romanello / Alison Babeu / Gregory Crane, Collecting Fragmentary Authors in a Digital Library, in: Proceedings of the 2009 Joint International Conference on Digital Libraries (JDCL 09, Austin, TX 2009), New York 2009, 259-62.

Bingen, Review = Jean Bingen, review of P.Lund VI, CE 29 (1954), 152-4.

Bonati, Lessico = Isabella Bonati, Il lessico dei vasi e dei contenitori greci nei papiri. Specimina per un repertorio lessicale degli angionimi greci, Berlin/Boston 2016.

Bonati/Reggiani, Mirrors = Isabella Bonati / Nicola Reggiani, Mirrors in the Greek Papyri: Question of Words, in: L. Diamantopoulou / M. Gerolemou (eds.), Mirrors and Mirroring: From Antiquity to the Early Modern Period. Proceedins of the Conference (Vienna 2017), forthcoming.

Boschetti, Methods = Federico Boschetti, Methods to Extend Greek and Latin Corpora with Variants and Conjectures: Mapping Critical Apparatuses onto Reference Text, in: Proceedings of the Corpus Linguistics Conference CL 2007 (Birmingham 2007), article \#150, URL: $<$ http:/www.birmingham.ac.uk/documents/college-artslaw/corpus/conference-archives/2007/ 150Paper.pdf>.

Collinet/Jouguet, Papyrus = Paul Collinet / Pierre Jouguet, Papyrus bilingue du Museé du Caire, APF 3 (1906), 339-48.

Colomo, Osservazioni $=$ Daniela Colomo, Osservazioni sullo scriba ossirinchita dell'omega quadrangolare (Johnson A2), "Segno \& Testo" 6 (2008), 3-34.

Crane, Editors = Gregory Crane, Give Us Editors! Re-inventing the Edition and Re-thinking the Humanities, in: F. Moody / B. Allen (eds.), Online Humanities Scholarship: The Shape of Things to Come, New York 2010, URL: <http://cnx.org/contents/XfgqFrtg@2/Give-us-editors-Reinventing-t>.

Cribiore, Criticism = Raffaella Cribiore, Genetic Criticism and the Papyri: Some Suggestions, in: N. Reggiani (ed.), Greek Medical Papyri: Text, Context, Hypertext. Proceedings of the DIGMEDTEXT International Conference (Parma 2016), Berlin/Boston 2019, 175-93.

Daniel, Papyri = Robert W. Daniel, Two Greek Magical Papyri, Köln 1991.

Daris, Spoglio I = Sergio Daris, Spoglio lessicale papirologico, I, Milano 1968. 
Depauw/Stolk, Variation = Mark Depauw / Joanne Stolk, Linguistic Variation in Greek Papyri: To wards a New Tool for Quantitative Studies, GRBS 55 (2015), 196-220.

Dover, Evolution = Kenneth J. Dover, The Evolution of Greek Prose Style, Oxford 1997.

Essler/Riaño Rufilanchas, AristachusX = Holger Essler / Daniel Riaño Rufilanchas, 'Aristarchus X' and Philodemus: Digital Linguistic Analysis of a Herculanean Text Corpus, in: J. Urbanik / T. Derda / A. Łajtar, Proceedings of the 27th International Congress of Papyrology (Warsaw 2013), Warsaw 2016, I, 491-501.

Evans, Language $=$ Trevor V. Evans, Identifying the Language of the Individual in the Zenon Archive, in: T. V. Evans / D. D. Obbink (eds.), The Language of the Papyri, Oxford 2010, 51-70.

Evans, Standard $=$ Trevor V. Evans, Standard Koine Greek in Third Century BC Papyri, in: T. Gagos (ed.), Proceedings of the Twenty-Fifth International Congress of Papyrology (Ann Arbor 2007), Ann Arbor 2010, 197-206.

Fournet, Bibliothèque = Jean-Luc Fournet, La bibliothèque d'un médecin ou d'un apothicaire de Lycopolis ?, in : I. Andorlini (ed.), Testi medici su papiro. Atti del Seminario di Studio (Firenze, 3-4 giugno 2002), Firenze 2004, 175-97.

Fournet, Papyrus = Jean-Luc Fournet, Un papyrus médical byzantin de l'Académie des Inscriptions et Belles-Lettres, "Travaux et Mémoires" 12 (1994), 309-22.

Gazza, Prescrizioni II = Vittorino Gazza, Prescrizioni mediche nei papiri dell'Egitto greco-romano. II, “Aegyptus” 36 (1956), 73-114.

Gignac, Grammar I = Francis T. Gignac, A Grammar of the Greek Papyri of the Roman and Byzantine Periods, I: Phonology, Milano.

Hanson, Fragmentation = Ann E. Hanson, Fragmentation and the Greek Medical Writers, in: G. W. Most (ed.), Collecting Fragments / Fragmente Sammeln, Göttingen 1997, 289-314.

Jördens, Entwurf = Andrea Jördens, Entwurf und Reinschrift - oder: Wie bitte ich um Entlassung aus der Untersuchungshaft, "Chiron” 47 (2017), 271-302.

Lewis, Documents = Naphtali Lewis, Two Greek Documents from Provincia Arabia, "Illinois Classical Studies" 3 (1978), 100-14.

Maas, Criticism = Paul Maas, Textual Criticism, Oxford 1958 [Textkritik, Leipzig 1957].

Maravela/Leith, Catechism = Anastasia Maravela / David Leith, A Medical Catechism on Tumours from the Collection of the Oslo University Library, in: J. Frösén / T. Purola / E. Salmenkivi (eds.), Proceedings of the $24^{\text {th }}$ International Congress of Papyrology (Helsinki 2004), Helsinki 2007, 637-50.

Maravela/Reggiani, Scribes = Anastasia Maravela / Nicola Reggiani, Medical Scribes at Work: Exploring Linguistic Variation in Greek Medical Papyri, in: S. Dahlgren / H. Halla-aho / M. Leiwo / M. Vierros (eds.), Act of the Scribe: Interfaces between Scribal Work and Language Use. Proceedings of the Workshop (Athens 2017), Helsinki, forthcoming.

Marganne, Fragment = Marie-Hélène Marganne, Un fragment du medecin Herodote: $P$. Tebt. II 272, in: Proceedings of the Sixteenth International Congress of Papyrology (New York 1980), Chico 1981, 73-8.

Mayser, Grammatik I = Edwin Mayser, Grammatik der griechischen Papyri aus der Ptolemäerzeit, I: Laut- und Wortlehre, Berlin/Leipzig 1923.

McNamee, Sigla $=$ Kathleen McNamee, Sigla and Select Marginalia in Greek Literary Papyri, Bruxelles 1992.

Mirizio, Antigrapha = Giuditta Mirizio, Amministrare e comunicare in Egitto tra III e II secolo a.C.: antigrapha e archetipi nella documentazione papiracea, PhD Diss., Bologna 2018.

Mirizio, Archetypes $=$ Giuditta Mirizio, Archetypes and Antigrapha in the Papyrological Documentation. Preliminary Considerations, AnPap 28 (2016), 255-71.

Nielsen, Catalog = Bruce E. Nielsen, A Catalog of Duplicate Papyri, ZPE 129 (2000), 187-214.

Perilli, Filologia = Lorenzo Perilli, Filologia computazionale, Roma 1995. 
Petit, Médecin = Caroline Petit (ed.), Galien: Le médecin. Introduction, Paris 2009.

Polotsky, Documents = H. J. Polotsky, Three Greek Documents from the Family Archive of Babatha, "Eretz Israel" 8 (1967), 46-51.

Porter/O'Donnell, Phenomena = Stanely E. Porter / Matthew B. O'Donnell, Building and Examining Linguistic Phenomena in a Corpus of Representative Papyri, in: T. V. Evans / D. D. Obbink (eds.), The Language of the Papyri, Oxford 2010, 287-311.

Reggiani, Concept $=$ Nicola Reggiani, The Corpus of the Greek Medical Papyri and a New Concept of Digital Critical Edition, in: N. Reggiani (ed.), Digital Papyrology II: New Methods for the Digital Edition of Ancient Greek Papyri, Berlin/Boston 2018, 3-61.

Reggiani, Digital Papyrology I = Nicola Reggiani, Digital Papyrology I: Methods, Tools and Trends, Berlin/Boston 2017.

Reggiani, Literacies = Nicola Reggiani, Ancient Doctors' Literacies and the Digital Edition of Papyri of Medical Content, "Classics@”, forthcoming.

Reggiani, Perspectives = Nicola Reggiani, The Corpus of Greek Medical Papyri and Digital Papyrology: New Perspectives from an Ongoing Project, in: M. Berti / F. Naether (eds.), Altertumswissenschaften in a Digital Age: Egyptology, Papyrology and Beyond. Proceedings of a conference and workshop (Leipzig 2015), Leipzig 2016, ch. 1.9, URL: <http://nbnresolving.de/urn:nbn:de:bsz:15-qucosa-201726>.

Reggiani, Project $=$ Nicola Reggiani, A Corpus of Literary Papyri Online. The Pilot Project of the Medical Texts via SoSOL, in: R. Lafer / K. Strobel (eds.), Antike Lebenswelten. Althistorische und papyrologische Studien, Berlin/Boston 2015, 341-52.

Reggiani, Tradurre = Nicola Reggiani, Tradurre, mediare, misurare: qualche nuova riflessione su hermēneus e hermēneia nei papiri (e una rivisitazione di P.Monts.Roca IV 71), ZPE, forthcoming.

Reggiani Transmission = Nicola Reggiani, Transmission of Recipes and Receptaria in Greek Medical Writings on Papyrus Between Ancient Text Production and Modern Digital Representation, in: E. Barile / R. Berardi / N. Bruno / M. Filosa / L. Fizzarotti (eds.), On the Track of Books: Scribes, Libraries and Textual Transmission, Berlin/Boston 2019, forthcoming.

Riaño Rufilanchas, Philodemus = Daniel Riaño Rufilanchas, The 'Grammatically Annotated Philodemus' Project, CErc 44 (2014), 155-65.

Sijpesteijn, Papyri = Pieter J. Sijpesteijn, Five Byzantine Papyri from the Michigan Collection, ZPE 62 (1986), 133-49.

Sosin, Updates = Joshua D. Sosin, Papyri.info Updates, "Digital Papyrology", December 1, 2011, URL: <http://digitalpapyrology.blogspot.it/2011/12/papyriinfo-updates.html>.

Stolk, Dative = Joanne V. Stolk, Dative by Genitive Replacement in the Greek Language of the Papyri: A Diachronic Account of Case Semantics, "Journal of Greek Linguistics" 15 (2015), 91-121.

Stolk, Encoding = Joanne V. Stolk, Encoding Linguistic Variation in Greek Documentary Papyri, in: N. Reggiani (ed.), Digital Papyrology II: New Methods for the Digital Edition of Ancient Greek Papyri, Berlin/Boston 2018, 119-37.

Stolk, Variations = Joanne V. Stolk, Case Variation in Greek Papyri. Retracing dative case syncretism in the language of the Greek documentary papyri and ostraca from Egypt (300 BCE -800 CE), PhD Diss., Oslo 2015.

Stoop, Copies = Jelle Stoop, Two Copies of a Royal Petition from Kerkeosiris, ZPE 189 (2014), 185-93.

Vierros, Annotation = Marja Vierros, Linguistic Annotation of the Digital Papyrological Corpus: Sematia, in: N. Reggiani (ed.), Digital Papyrology II. New Methods for the Digital Edition of Ancient Greek Papyri, Berlin/Boston 2018, 105-18.

Vierros/Henriksson, Preprocessing = Marja Vierros / Erik Henriksson, Preprocessing Greek Papyri for Linguistic Annotation, in: M. Büchler / L. Mellerin (eds.), Computer-Aided Processing of Intertextuality in Ancient Languages, "Journal of Data Mining and Digital Humanities", special issue, 2017, URL: <http://jdmdh.episciences.org/paper/view/id/1385>. 
Willis, Data Bank = William H. Willis, The Duke Data Bank of Documentary Papyri, in: Atti del XVII Congresso Internazionale di Papirologia (Napoli 1983), Napoli 1984, I, $167-73$.

Youtie, Criticism = Herbert C. Youtie, The Textual Criticism of Documentary Papyri. Prolegomena. Second Edition (BICS Suppl. 33), London 1974.

Yuen-Collingridge/Choat, Copyist $=$ Rachel Yuen-Collingridge $/$ Malcolm Choat, The Copyist at Work: Scribal Practice in Duplicate Documents, in: P. Schubert (ed.), Actes du 26e Congres international de papyrologie (Genève 2010), Genève 2012, 827-84. 